\title{
Aile, Çocuk ve Sosyal Politika
}

\author{
Mustafa Ruhi Șirin
}

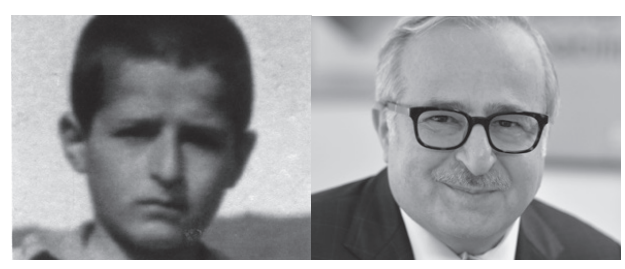

\section{Aileyi Ne Kadar Tanıyoruz?}

Türkiye, 1. Aile Şûrası'ndan” önce ve sonra “Ailenin geleneksel temelleri ile sosyal gelişme ve modernleşme unsurları arasındaki çatışan ve uzlaşan tarafların tespit edilmesi ve aileye yönelik politikalar" (1990, s. 29) geliştirememiş bir ülke görüntüsü içindedir. 1. Aile Şûrası'nda; “aile araştırmaları için, 'ideolojik' olarak nitelendirilebilecek, 'evrensel', 'tekdoğrulu' ve 'tek yönlü' evrim modelleri ile yaklaşmanın hatalı olduğu; 'izlenecek yöntem' 'parça-bütün' bağlantısını gözden kaçırmayan, 'çok değişkenli', 'bütüncül' yaklaşımla ailenin iç ve dış etkileşimlerini ve dinamiklerini" (1990, s. 205) araştırma ve inceleme aşamasına da gelinemediği tespitine rağmen, Türkiye hâlâ Aile Politikası ve Sosyal Programı geliştirememiştir.

Türkiye'de toplumun aileyi ve çocuğu nasıl etkilediğini araştıran ve inceleyen çalışmaların yapılmamış olması düşündürücüdür. 1970'lerin sonuna doğru 9 dünya ülkesinde yapılan “Çocuğun Değeri” Araştırması "ana-babaların çocuk sahibi olma konusunda güdülenmeleri ve çocuğa yükledikleri değerleri ortaya" çıkarmayı amaçlamıştı. Almanya ve Endonezya dışında tüm ülke nüfuslarını temsil eden örneklerin kullanıldığı bu araştırmada çocuğun psikolojik ve ekonomik değeri ön plana çıkmıştı. 2021/1
* İlk Aile Şûrası 17-20 Aralık 1990 yılında Ankara'da düzenlenmiş; yedi komisyon aile hakkında bildirileri müzakere etmiş, durum tespitine yönelik görüşlerin ortaya çıkması sağlanmış ve kararlar almıştı. 
Bu araştırmaya göre, "çocuklara yüklenen değerler ve onlardan beklenenler aslında ailenin ne şekilde işlediğini” yansıttığını; "ülke içindeki farklılıkların sosyo-ekonomik gelişme bakımından kültürlerarası olanlarla aynı doğrultuda" olduğunu gösteriyor (Kâğıtçıbaşı, 1990, 95-98). 1980 sonrası aile ve çocuğun durumu hakkındaki veriler dışında bilgilerimiz çok sınırlı. Aile yanında çocuğun göstergelerini de bilmiyoruz. Oluşmakta olan yeni çocukluk sosyolojisi ile birlikte modern çocuk kültürü aile-çocuk ilişkilerini çocuğu merkeze alan bir boyuta taşıdı. Dünya, her aile sorununun bir çocuk sorununa dönüştüğü bir aşamaya doğru evrilirken öngörülerle mi yetineceğiz? Yoksa yeniden aile ve çocuğu tanımaya ve anlamaya mı yöneleceğiz?

Türkiye toplumunun en önemli üç özelliği duygusallık, çocuk severlik -aşırı çocuk duygusu- ve yardımlaşmadır. Bu üç özelliğin merkezindeki kurum aile olduğu hâlde, aile ve toplum içinde çocuk ve kadına verilen değer anlayışı aynı zamanda bir dizi sorunlar içeriyor. Aile sorunlarını sosyal bilimlerin havuzundaki sonuçlara göre değil de sadece resmî ideoloji ve politika inşa süreçleri üzerinden tartışmak ise çözüme yönelmeyi engellemektedir. Çok sık tekrarlanan bu yanlıştan uzaklaşmak özellikle aile ve çocukluk sosyolojisini merkeze alarak aile ve çocuk sorunlarına eğilmekle mümkün olabilir. Bunun için de öncelikle sosyal bilim çevrelerinin ve politika yapıcıların aile ve çocuk dersine çok iyi çalışmaları gerekir.

Türkiye toplumunda kültürel yoğunluğun azalması, değer üretememenin eşiğine gelinmesi, sosyal dokunun zayıflaması ve toplumsal fay hatlarındaki gerilim dört sarmalın genişlemesine neden oluyor: Toplumda ayrışma, sosyal dayanışmanın zayıflaması, güvensizlik ve toplumsal psikolojinin daha kırılgan duruma gelmesi... Bu dört sarmalın birinci derecede etkilediği kurum yine aile kurumudur. Sonuçları ise değerlerin zayıflaması, özellikle çocuğa ve kadına karşı şiddet, aileye yönelik suçlarda artış ve boşanma olarak karşımıza çıkıyor.

Türkiye'de ailenin kırılganlaşan öncelikli sosyolojik gerçeklerini şöyle sıralayabiliriz: Yoksulluk, işsizlik, göç, gelir dağılımı bozukluğu, sosyal yardıma ihtiyaç duyan hane halkı sayısının sürekli artmakta oluşu, bölgeler arası eşitsizlik ve sosyal güvencesizlik... Ailenin bu iç ve dış kırılganlıkları ailede sosyal değişimi hızlandırdığı gibi, aile geleneğinin zayıflamasına da neden olmaktadır. Kültürel geleneğin yoğunluğunun azalması ailenin hayat çemberi içinde çocuğa değer aktarımını zayıflattığı gibi aile geleneğini olumsuz yönde etkilemektedir. Sosyal politikacıların farkına varamadığı ailenin dönüşmesi konusunun nedeni ise çaresizlik sarmalının genişlemesidir.

Çocuk ve Medeniyet 2021/1
Bu noktada “Aileyi ne kadar taniyoruz?" sorusunu tekrar sormamız gerekecek: İnsanlık tarihi boyunca en güvenilir kurumun aile olduğu sadece bir ön 
kabuldür. Türkiye'de aile gerçeğini bütün boyutları ile ne toplum biliyor ne de devlet. Buna rağmen ailenin hâllerini genel kanaatlerle yorumlamakla meşgulüz. Türkiye'de devlet, hâlâ "baba"dır. Dönemlere göre yardımlarını azaltır, çoğaltır, bazen daha da cömert olur. Fakat bir türlü yardım temelli anlayıştan kurtulamaz ve Hak ve Sorumluluk Temelli anlayışa geçemez.

\section{Önce Sosyal Koruma Hukuku}

Devletin yaptığı yardımların sosyal politika ile ilişkisi olmadığı tezini savunuyor değiliz. Yardım temelli günlük sosyal yardımlar sosyal politikanın en alt düzeyidir. Bu tür yardım türleri güç koşullardaki hane halkının ihtiyaçlarını geçici süre için giderse de mağduriyetin kökenine inilmedikçe ne yoksulluk sarmalı çözülebilir ne de sosyal koruma hukuku anlayışına geçilebilir.

Cumhuriyet Dönemi'nde yapılan sosyal yardımların birkaç kat fazlası son yıllarda yapıldığı hâlde, aile sorunları azalmadığı gibi, aksine daha da giriftleşmektedir. Bu konuda Türkiye'de başarı sağlanan çok önemli üç somut sosyal politika örneği vardır: Engelliler Yasası (2005), ailesi sosyal güvenceden mahrum 0-18 yaş grubu çocukların "sağlık güvencesi”ne (2006) kavuşturulması ve açlık sınırının altında yaşayan insanın kalmamış olması. Sosyal yardımların artırıldığı gerçeğine rağmen, Türkiye'de 7 milyonu aşkın hane halkı, diğer açıdan nüfusun 29 milyonu yoksulluk sınırında yaşamaktadır. Ekonomik büyümeye paralel olmasa da sosyal yardımlardaki bu artışlarla devletin Hak ve Sorumluluk Temelli bir sosyal devlete dönüşme imkânı yoktur. Çünkü bu yardım anlayışı ekonomik büyümeyle sınırlı bir sosyal politika tercihidir.

Türkiye'de sürdürülmekte olan bir anlayışı hatırlatmakta yarar var: Kalkınma planları ile “yapısal dönüşüm”ün gerçekleşeceği öngörülmüştü. Son plan, farklı paydaşların temennilerinden seçilmiş vaatler kataloğu olarak hazırlanmıştı. Plan, ne ülke ölçekli somut model, ne de sistem önermektedir. Sosyal koruma hukuku yaklaşımına tek bir yerde bile atıfta bulunulmamıştır. Ekonomik büyümeye dayalı kalkınma hedeflerine öncelik veren son planın ne misyon ne de vizyon bakımından önceki planlardan farklı yanı da yoktur. En cılız yönü, kültürel boyuttan yoksun oluşudur. Model ve sistem öngörüsü olmayan bu planla “yapısal dönüşüm”ün gerçekleşme ihtimalinden söz etmek de gerçekçi değildir.

Çocuk ve Medeniyet 2021/1
Türkiye'nin içinde bulunduğu sosyal dönüşüm süreci nedeniyle yönetilmesinin zorlaştı̆̆ı gerçeği, aile sorunlarıyla daha yakından ilgilenmeyi zorunlu kılmaktadır. "1995'lerden bu yana toplum ve ailenin, 
aile politikalarının alabildiğine sahipsiz kaldığını söylemek zor olmamalıdır. Toplumsal hayat, siyasal gelişmelerden daha hızlı evrilmekte; bilim ve düşünce çevreleri siyasal gelişmelerin takibini öne alırken, toplumu ve aileyi, yaşadığımız derin istihaleleri büsbütün gözden kaçırabilmektedirler." (Turinay, 2011, s.104). Aileye yönelmek için iki temel öncülden hareket edilebilir: Sosyal bilimlerin oluşturduğu havuza yansıyan aile yapısının büyük resmi dikkate alınarak Sosyal Politika Stratejisi ve 25 yılı kapsamak üzere yapılandıracak ve uygulanacak Sosyal ve Kültürel Program hazirlanmasi.

Bu noktada şu ana soru sorulabilir: Aile sorunlarının çözümü niçin erteleniyor? Öncelikli iki neden üzerinde durulabilir: Önleyici, koruyucu, geliştirici yaygın eğitimin yüksek maliyeti, bir. Ülke ölçekli Sosyal ve Kültürel Program üzerine hazırlık yapılmamış olması, iki. 6 Aile Şûrası'nın kararları dâhil, son 5 yıllık Kalkınma Planları, Hükümet Programları ve Cumhurbaşkanlığı Hükümet Sistemi'nde ülke ölçekli önleyici, koruyucu ve geliştirici bir Sosyal ve Kültürel Programa atıfta bile bulunulmamış olması da bu iki nedenle ilişkilidir. Oysa içinde bulunduğumuz ve her geçen gün daha da kırılganlaşan zaman diliminde öncelikle sosyal ve kültürel programa acilen ihtiyaç vardır. Bu programa, çocukla ilgili Adlî ve Sosyal Sistemi de dâhil etmek gerekir.

Gündemdeki aile içi ve toplumsal şiddet, küresel boyutları ile hem aile hem de toplum açısından çok bileşenli bir sarmaldır. Şiddetin artış nedenleri hem ülke hem de küresel boyutludur. Fakat değişmez bir kural vardır: Aile bir şeyleri örtmüşse bu örtülenler bir gün görünür olur ve açığa çıkar.

Aile merkezli sosyal politika "yaygın eğitim"le bire bir ilişkilidir. Millî Eğitim Bakanlığı'nın görevleri arasındaki “örgün ve yaygın eğitim”in birbirinden ayrılması artık zorunluluk hâline gelmiştir. MEB'in "örgün eğitime" odaklanması ve "yaygın eğitim"in kurulacak Aile ve Çocuk Bakanlığı'na devredilmesi gerekmektedir. Aile ve Çocuk Bakanlığı'nın amacı ve işlevi, "yaygın eğitim"i de kapsayacak şekilde yeniden düzenlenmedikçe, Bakanlığın yerel yönetimlerle ilişkisi kurulmadıkça ve icracı bir yapıya dönüştürülmedikçe, Türkiye'de uygulanacak aile odaklı çocuk merkezli sosyal politikaların başarı şansı çok zayıftır.

Çocuk ve Medeniyet 2021/1

\section{Temel Politika ve Strateji Eksikliği}

Türkiye, nüfusunun yüzde 90'a yakını kasaba, şehir ve büyükşehirlerde yaşayan çok hareketli demografik yapıya sahip bir ülkedir. Nüfusun yüzde 28.3'ünüi 0-17 yaş aralığındaki çocuklar oluşturmaktadır. Türkiye, toplam 
doğurganlık hızı 2.07, ortalama hane halkı büyüklüğü 3.4 ve 22.676.186 hane halkı yapısı ile hızlı değişim ve dönüşümünü sürdürmektedir. Bu değişim/dönüşümle birlikte bir taraftan hareketli olduğu kadar diğer taraftan yorgun bir toplum görüntüsü içindedir.

Türkiye ayrıca çok yönlü modernleşme kuşatması sonucu üretilmiş değerleri tüketen aile yapısına doğru evrilmektedir. Bu yönüyle kültür ve medeniyet değerlerinin zayıfladığı ve hayat çemberi içinde kültürel yoğunluğun azaldığı bir ülke görüntüsü içindedir. 1980 sonrası hızlanan sosyal yapıdaki çözülmenin ailenin bütün bireylerini etkilediği ve aileyi sorunlarını çözemez duruma getirdiği hususu ise ortak kabullerden biri durumuna gelmiştir.

Temel politika ve strateji eksikliği nedeniyle sarmala dönüşen sosyal sorunlar çözülemediği gibi, her bir sorun alanı birbiriyle ilişkili yeni sorunların ortaya çıkmasına neden olmaktadır. Cumhuriyet Dönemi'nden bu yana ve özellikle son 15 yılda başta engellilerle ilgili olmak üzere, sosyal haklar konusunda çok önemli yasal düzenlemeler yapıldığı ve sosyal yardımlar her geçen yıl artırıldığı hâlde, aile ve güç koşullardaki bireylerin eğitim ve işsizlik sorunlarının ertelenmiş ve çözülememiş olmasının nedeni ise ülke ölçekli temel politika, strateji ve program eksikliğidir.

Bu noktadan hareketle son çeyrek yüzyıl içinde Türkiye'de ailenin sosyal boyutuyla ilgili araştırmalar, 5 Yıllık Kalkınma Planları, Hükûmet Programları, TÜİK'in aileyle ilgili açıkladığı göstergeler ve son İnsani Gelişme Endeksi dikkate alındığında şu tespitin yapılması gerekmektedir: Türkiye'nin sosyal yapısı içinde aile, çocuk ve gençlik sorunları ilk defa yoksulluk, güvenlik, ekonomi, eğitim ve dış politikanın önüne geçmiştir. Aile, çocuk ve gençlik meselesi Türkiye'nin birincil beka meselesidir.

\section{Çözüimüi Ertelenen Sorunlar}

Aile ve Çocuğun İyilik Hâli Endeksi Sistemi kurulamamış olmasına rağmen, Türkiye'nin İnsani Gelişme Endeksi'ndeki göstergeler ve TÜİK verileri üzerinden şu tespitler de yapılabilir: Aile içi sorunlar, çocuk yetiştirme geleneği, kadın ve erkek sorunları, boşanma oranlarının artması, iki kişilik ve tek kişilik hane sayısının sürekli artış göstermesi, engelli bireylerin eğitiminin ihmal edilmesi, gençliğin işsizliği ve umutsuzluğu, yaşlıların toplum içinde yalnızlaşması, çocuk iş gücü istismarı, yüzde 10'u aşan işsizlik, güç koşullardaki çocuklar, yurt dışındaki çocuk ve gençlerle ilgili

Çocuk ve Medeniyet 2021/1 politika eksikliği, yoksulluk ve çocuk yoksulluğu alanlarındaki sorunların çözümünde devletin yükümlülükleri yerine getirebilmesi için daha etkin bir örgütlenmeye acil olarak ihtiyaç vardır. 
Türkiye'nin aile özelinde çocuk, gençlik, kadın, engelli, yaşlı ve tüm güç koşullardaki öznelerin sorunlarının çözümüne yönelmesi için iki üst politika hedefini gerçekleştirmesi gerekmektedir: Tüm boyutlarıyla ülke ölçekli Sosyal Politika Stratejisi ve 25 yılı kapsayacak Sosyal ve Kültürel Programın hazırlanması. Eş zamanlı olarak Aile ve Çocuk Bakanlığı'nın kurulması.

Cumhuriyet tarihi boyunca sosyal politikalar alanında faaliyet gösteren kamu kuruluşları sorunların ortaya çıktıktan sonra bireylerin talebi üzerine devreye giren ve ihtiyacın giderilmesini sosyal yardım dağıtarak sağlamaya çalışan anlayış üzerine inşa edilmiştir. Yeni kurulacak bakanlığın işlevi sorunlar ortaya çıkmadan, sorunları önlemeye yönelik politikalar ve sosyal hizmet modelleri üzerinden belirlenmelidir. Bunu sağlamak için sosyal yardımı "lütuf" yerine insanların sosyal haklarının karşılanmasını esas alan Hak ve Sorumluluk Temelli anlayışa göre yapılandırma yoluna gidilmelidir. Kurulacak bakanlık Millî Eğitim Bakanlığı'ndan devralınması gereken yaygın eğitim hizmetlerinin koordinasyonunu sağlamak, hizmet alanları ve modelleriyle ilgili standartları belirlemek yanında İzleme ve Denetleme görevlerini de üstlenmelidir. Yeni bakanlığın kuruluş aşamasında mevcut bakanlığın yürütmekte olduğu hizmetlerin topluma daha kolay ulaştırılması amacıyla bu görevlerinin yerel yönetimlere devredilmesi tercih edilmelidir.

Aile ve Çocuk Bakanlığı'nın görevleri arasında ilgili bakanlıklarla eş güdüm ve etkin koordinasyon işlevleri de yer almalıdır. Yeni bakanlıkla birlikte Kamu Denetçiliği Yasası'nda da değişiklik yapılarak her biri ayrı ayrı olmak üzere Aile, Çocuk, Gençlik, Kadın, Yaşlılar Ombudsmanlı̆̆ı da öngörülmelidir. Ayrıca, TBMM'de daimi görev yapacak Aile, Çocuk, Gençlik ve Kadın Komisyonu kurulması düşünülmelidir.

Kurulmasını önerdiğimiz Aile ve Çocuk Bakanlı̆̆ı ailenin tüm özneleri ve toplumsal bileşenlerini kapsayacak şekilde ve icracı bir yapıda kurulabilirse bakanlık sosyal politika uygulamaları ile sorunların çözümüne yönelebilir ve insan odaklı bir işlevi yerine getirmeye başlayabilir. 